\title{
Biomass Briquettes as an Alternative Source of Cooking Fuel towards Green Recovery Post COVID-19
}

\author{
Ibrahim $\mathrm{MS}^{1 *}$, Bello $\mathrm{S}^{2}$, Ibrahim $\mathrm{A}^{3,4}$
}

${ }^{1}$ Department of Polymer and Textile Engineering, Ahmadu Bello University Zaria-Nigeria

${ }^{2}$ Ministry of Environment and Natural Resources, Kaduna State

${ }^{3}$ Department of Geography and Environmental Management, Ahmadu Bello University Zaria-Nigeria

${ }^{4}$ Department of Education, Babcock University Nigeria

DOI: $10.36348 /$ sjet.2020.v05i06.005

| Received: 12.06 .2020 | Accepted: 20.06.2020 | Published: 30.06 .2020

*Corresponding author: Ibrahim M. S

\section{Abstract}

Biomass briquettes can be considered as the best alternative energy source compared to wood fuel. Clean energy in households is a tool to improve human health, lower climate change impacts and save hundreds of millions of people, especially for women and children from toiling during daily fuel collection. To achieve a progressive response in sustainable development Goals, Clean and efficient household energy will improve health, gender equality, sustainable urban environments, and climate action and green recovery post COVID-19. The adoption of the energy from biomass briquettes would help Improve access and adoption of the life changing products to end users influencing their lives socially, economically and financially, improve sales and stability which will translate to more employment and more taxes for the government and improve the economy of Nigeria, achievement of NDC commitment of $20 \%-45 \%$ emission reduction, generally improve the standard of living and productivity of the end users and also safeguard the environment for future generation. It is therefore recommended that; Legislate policies prosecuting individuals and companies indiscriminately clogging trees for wood fuel and charcoal production binding ministry of forestry, Agriculture and environment with such task, Fund research in order to provide various sustainable raw materials for briquettes production with high calorific value and Provide forest guards with adequate resources and welfare to safeguard our green cover, wildlife and other natural resources.

Keywords: Biomass, Briquettes, Cooking Fuel, Energy, Wood Fuel, Climate Change, Greenhouse Gases.

Copyright @ 2020: This is an open-access article distributed under the terms of the Creative Commons Attribution license which permits unrestricted use, distribution, and reproduction in any medium for non-commercial use (NonCommercial, or CC-BY-NC) provided the original author and source are credited.

\section{INTRODUCTION}

The coronavirus pandemic has pushed Governments currently facing a stark choice: bail out polluting businesses, using that as leverage to impose environmentally-minded reforms, or let them return to their carbon-intensive activities as an economic quick fix. The best alternative is to contribute towards tackling the climate change crisis, but the cooking energy paradigm shift would be a significant landmark towards green recovery especially in Africa. Reports according to the World Health Organization iterated that about $52 \%$ which is more than half of the world population relies on wood, solid biomass and coal as source of energy for heating and cooking [1]. Since human origin, humans have used biomass, wood and other forest residues as fuel for heating and cooking their food. According to Wrangham [2] a defining moment which is a nexus between pre-human and human condition putting in place practice to control fire. A millennium ago, resulting from the agricultural revolution, agricultural waste was given utmost consideration in an attempt to valorize them. Coal is put into use as an energy source for heating and cooking in some parts of the world where coal has been mined such as the British Isles and China dated back to a millennium ago [3]. Wood, agricultural residues, and coal constitute the solid cooking fuels used by about 40 percent of humanity today [4-5]. Typically burned in simple cook stoves, these fuels produce smoke that is now understood to cause a large burden of disease [5]. Indoor greenhouse gases generated as a result of wood fuel usage for cooking has always been detrimental to the lives and health of women, amounting to 3-4 million premature deaths annually and a wide range of illnesses in the developing world [1], According to WHO [6], it is estimated that developing countries with high mortality rate overall, indoor air pollution ranks fourth in terms of the risk factors that contribute to disease and death, out of which more than half of these deaths occur 
Ibrahim MS et al., Saudi J Eng Technol, June., 2020; 5(6): 285-290

among children under five years of age. There is therefore a need to develop green sources that can minimize toxic emissions. Thus, the most available alternative becomes renewable biomass briquettes produced from biomass emanating from forestry and agricultural residues emitting limited amount of greenhouse gas (GHGs) factor, notwithstanding, the reported levels of nitrogen dioxide (NO2) which is usually as a result of the use of agricultural fertilizers [7].

Indoor greenhouse gases or household air pollution impacts public health [8-9], and contributes to climate change [10-11]. Despite a major shift in the household energy types used, many households rely solely on charcoal as their primary source of cooking energy, especially in urban areas [12]. The burning of fossil fuel and wood for cooking and heating lead to discharge of fine particles (i.e ground-level ozone) in our surrounding, as a result of chemical reactions between other molecules present in the atmosphere, mostly the Nitrogen Oxide and Volatile Organic Compounds. These two air pollutants have direct effects on health as they penetrate with cold air during respiration increasing the risk of asthmatic attacks, lungs and heart disease. Long-term exposure increases the chances of chronic bronchitis, cardiovascular disease and chronic obstructive lung disease (COPD) [13]. In the light of the pandemic that cripples the world's largest economies, all Covid-19 recovery investments should go towards commerce that either helps reduce carbon emissions or promotes digital business towards green recovery and attaining climate action, therefore the need to adopt the use of biomass energy resources is deemed significant.

\section{Briquettes}

Biomass Briquettes are the compressed blocks of Agro \& Forestry residues. The wastes may include rice husk, soya husk coffee husk, Coir Pitch, Jute Sticks, Sugarcane Bagasse, Groundnut Shell, Mustard Stalks, Cotton Stalks, Saw Dust, Castor seed Shells/Stalk, Wood Chips, Bamboo Dust, Tobacco Waste, Tea Waste, Paddy Straw, Wheat Straw, Sunflower Stalk, Palm Husk, Veneer Residues, Barks and Straw, Forestry Waste, seeds Cases, etc [14-21]. Nigeria as an agricultural based developing country, abundant amount of agricultural solid waste is generated annually, a country with available land area of about 91,077,000ha of which agriculture covers $71,000,000$ ha [12, 22-24]. Burning the agricultural biomass waste causes a lot of pollution. Hence conversion to briquettes reduces to the barest minimum the pollution and increases the burning time [25-27], and thus, a reliable and sustainable substitute for nonrenewable energy resources. Various agricultural biomasses have proven to be effective in briquettes production [15-21, 28-31]. Briquette technology, as an important waste management system for the agricultural waste/biomass, has always contributed to offset forest and fossil fuels thereby limiting the rate of deforestation and desertification owe to over dependence on forest fuel (wood), bio-residue management issues and limit emissions of toxic greenhouse gases from incomplete toxic combustion of natural plant resources not to mention energy production development [21, 32-36]. Briquettes possesses an important characteristic owe to its calorific value, according to the IEA [37], calorific value of an energy source (fuel) otherwise known as heat of combustion or heating value or heat value is the energy released per unit mass of fuel by undergoing complete combustion in the presence of excess oxygen. According to [38] the calorific value for some biomass used for briquettes production such as Corn stalk/Stover, sugar cane bagasse, Wheat straw, grass, rice straw and rice husk are $16,800-18,500 \mathrm{KJ} / \mathrm{Kg}$, $17,700-19,400 \mathrm{KJ} / \mathrm{Kg}, \quad 15,000-18,900 \mathrm{KJ} / \mathrm{Kg}, \quad 17,000-$ $18,100 \mathrm{KJ} / \mathrm{Kg} \quad 13,500-14,800 \mathrm{KJ} / \mathrm{Kg}$ and 14,200 $15,400 \mathrm{KJ} / \mathrm{Kg}$ respectively. Therefore, biomass briquettes possesses a calorific value that's make it's a suitable energy generating fuel as agreed iterated by [26-31]. Kumar et al. [21] evaluates the efficiency of biomass briquettes and reported that the calorific values are better values and the highest calorific value is $20945 \mathrm{kj} / \mathrm{kg}$ and the maximum efficiency obtained is $80.79 \%$. Literatures identified the efficiency of briquettes as a renewable sustainable energy source [3946,]. Biomass briquettes can therefore, be considered an alternative cooking energy sources for green recovery post COVID-19.

\section{Economic Benefits}

Briquette value chain is a potential employer of people from production to final consumption. It is an emerging large employer of labour in its various phases of production which includes: collection agricultural/forestry residue/waste; preparation and carbonization for biomass that needs carbonization; drying and packaging; transportation and distribution [47-50]. High calorific value coupled with readily available agricultural/forestry waste makes it more efficient and reduces the production cost. Thus, makes briquette more affordable reducing the cost household spent on firewood which can be better used for nutrition, health and education [26-31].

Also the remediation as a result of deforestation as a result of inefficient use of firewood is high with a long term adverse effect to the environment. Hence briquette stands to replace firewood in households to reduce deforestation and mitigate environmental degradation as a result of over exploitation [49-51]. Locally added value, fostering local or regional businesses along the supply chain (forest operators, transportation and warehousing, briquette manufacturers, dealers, installers and maintenance services providers, etc.). 
Ibrahim MS et al., Saudi J Eng Technol, June., 2020; 5(6): 285-290

\section{Social Benefits}

According to the World Health Organization [52], household air pollution is the most essential environmental health risk worldwide, thus, women and children are at high risk from exposure. Women and girls bear the largest health burden from domestic pollution sources, ranging from collection to usage posing health risks which lead to their high mortality rate globally owing to indoor greenhouse gas emissions [52]. The adoption of biomass briquettes as alternative cooking fuel sources would significantly improve the health and wellbeing of women and children especially in marginalized communities and hence providing such communities with abundant natural resources and green cover thereby protecting over dependence and protection of life on land and reduction of greenhouse gases from logging and other actions exploiting natural resources [52]. The social benefits (total benefit to society from production and/or consumption of briquettes) is one of marvel as opined by $\mathrm{Hu}$ et al. [4951]. Briquettes have wide range of benefits that includes all the private benefits ranging from health hazards incurred from the procurement of other sourcewise harmful fuel source such as trees in forests down to the external benefits of production/consumption as it has become a means of livelihood for a wide range of local fuel-based business owners. If a good has significant external benefits, then the social benefit will be greater than the private benefit and that holds true in the case of briquettes as there are now hundreds of farmers in northern Nigeria that gain from giving out their farm waste in bulk to briquettes producers for briquettes production. This creates a spiral of diagonal and lateral development as it is another source of income for farmers when they might be out of seasonhence being able to feed their families, and for community, there is increased level to which they become more aware of incident environmental and societal hazards of the use of other sources such as fuelwood as well as the realization of the positive facts of economic values especially considering Philips et al. [53] perspective on forestry issues [53-57]. It is wholly correct to say that briquettes, without doubt have significant social benefits of bridging the gap between low income regions and mid-level small and medium scale enterprises that are interested in these raw materials for production and creates a spiral of synchronization between both classes of producers, the grassroots and the metropolitan regions and the industries and farmers as other collaborations might set in such as of agro-allied natures, amongst others.

\section{Environmental Benefits}

Briquettes are a renewable source of fuel and energy. The raw materials are abundant. Nature itself produces millions of tonnes of biodegradable waste which can be converted to briquettes. This can be agricultural or forestry waste. Owing to the fact that majority of Nigerians are living below the poverty line of $\$ 1.9$ per day, rising demand for energy is a major challenge facing the teeming population today, wood and charcoal are the principal cooking and heating fuels in Nigeria [37,58-64]. These are gotten by felling trees which has negative impacts to the environment and climate leading to deforestation, desert encroachment and soil erosion [53-55]. Tree felling also leads to food insecurity [53-57]. The increasing demand for clean energy, the focus on impacts of climate change and the urgent need for GHG emissions reduction is a major challenge to emerging sources of energy and Nigeria isn't an exception. Sustainability of biofuels in respect to the environment is defined primarily in terms of $\mathrm{CO}_{2}$, Methane and $\mathrm{N}_{2} \mathrm{O}$ (GHG) emissions mitigation (reduction), and other emissions e.g. in agriculture [56]. Moreover, if forests are converted into agricultural land for biomass generation, the GHG mitigation potential will differ from biomass generation from already available agricultural land. Thus, far, research on biomass and GHG emissions imply that land use remains unchanged [14, 32-36, 56].

Consequently, rice husk constitutes one of the major environmental nuisances as it forms the major municipal solid waste heaps in the areas where it is disposed which are mostly burnt in open fields which causes widespread environmental concerns owe to its pollution and GHG emission capability. Thus, owing to the health and environmental concerns, new regulations are imposed globally to restrict field burning activities. Subsequently, methods to dispose and to use agricultural residues such as rice straw and rice husk, bagasse, corn stalk, leaves etc. have shifted towards the global "waste to resource" agenda [22, 64]. Moreover, using biomass briquette will contribute immensely to sustainable forest management; neutralize $\mathrm{CO} 2$ emissions balance by reducing to about $60 \%$ and lower sulfur emissions (which usually causes acid rain).

\section{CONCLUSION}

Therefore, biomass briquettes can be considered as the best alternative energy source compared to wood fuel. Clean energy in households is a tool to improve human health, lower climate change impacts and save hundreds of millions of people, especially for women and children from toiling during daily fuel collection. To achieve a progressive response in sustainable development Goals, Clean and efficient household energy will improve health, gender equality, sustainable urban environments, and climate action and green recovery post COVID-19. The adoption of the energy from biomass briquettes would help Improve access and adoption of the life changing products to end users, improved sales and stability which will translate to more employment and more taxes for the government and improve the economy of Nigeria, achievement of NDC commitment of $20 \%-45 \%$ emission reduction, generally improve the standard of living and productivity of the end users and also safeguard the environment for future generation 
Ibrahim MS et al., Saudi J Eng Technol, June., 2020; 5(6): 285-290

\section{RECOMMENDATIONS}

For sustainability in supply of biomass briquettes as cooking fuels in developing countries, it is crucial to;

- Legislate policies prosecuting individuals and companies indiscriminately clogging trees for wood fuel and charcoal production binding ministry of forestry, Agriculture and environment with such task

- Fund research in order to provide various sustainable raw materials for briquettes production with high calorific value

- Provide forest guards with adequate resources and welfare to safe guard our green cover, wildlife and other natural resources

- $\quad$ Fund SMEs producing briquettes by providing soft loans of equipment to support mass production of briquettes to cater for the nations cooking energy needs

- Create awareness at the grassroots on the urgent need to combat climate change and its impacts and also the need to protect our green cover and embrace climate smart agriculture

\section{REFERENCE}

1. World Health Organization. (2020). Air Pollution, percentage of population using biomass fuels, Millennium Indicators Database, United Nations, Department of Economic and Social Affairs, Economic and Social Development, Statistics Division.

(http://millenniumindicators.un.org/unsd/mi/mi_ser ies_results.asp?rowId=712). Retrieved Thursday April $16^{\text {th }}, 2020$

2. Wrangham, R.W. (2009). Catching Fire: How Cooking Made Us Human. New York: Basic Books.

3. Smil, V. (1994). Energy and World History. Boulder, CO: Westview Press.

4. https://briquettesolution.com/bio-and-fuelbriquette-calorific-value-biomass-sawdust-coalcharcoal/

5. Smith, K.R, Sagar, A. (2014). "Making the Clean Available: Escaping India's Chulha Trap." Energy Policy 75 (December):410-14.

6. WHO, ed. (2002). The World Report 2002: Reducing Risks, Promoting Healthy Life. Geneva, World Health Organization

7. Ding, W., Luo, J., Li, J., Yu, H., Fan, J., \& Liu, D. (2013). Effect of long-term compost and inorganic fertilizer application on background $\mathrm{N} 2 \mathrm{O}$ and fertilizer-induced $\mathrm{N} 2 \mathrm{O}$ emissions from an intensively cultivated soil. Science of the total environment, 465, 115-124.

8. Smith, K. R., Bruce, N., Balakrishnan, K., AdairRohani, H., Balmes, J., Chafe, Z., ... \& Rehfuess, E. (2014). Millions dead: how do we know and what does it mean? Methods used in the comparative risk assessment of household air pollution. Annual review of public health, 35, 185206.

9. World Health Organization. (2014). WHO guidelines for indoor air quality: household fuel combustion. World Health Organization.

10. Bond, T. C., Doherty, S. J., Fahey, D. W., Forster, P. M., Berntsen, T., DeAngelo, B. J., ... \& Kinne, S. (2013). Bounding the role of black carbon in the climate system: A scientific assessment. Journal of Geophysical Research: Atmospheres, 118(11), 5380-5552.

11. Lacey F, Henze D. Global climate impacts of country-level primary carbonaceous aerosol from solid-fuel cookstove emissions. Environmental Research Letters. 2015 Oct 28;10(11):114003.

12. FAO.(2014). FAO Country Profiles. Ctry Profiles Top Imports United Kingdom. http://www.fao.org/countryprofiles/index/en/?iso3= NGA $>$ [accessed 17.01.16]

13.

(https://www.pca.state.mn.us/sites/default/files/aq1 -61.pdf)

14. Pavan, K.R., Dr. M. S. Bhagyashekhar. (2016). Development of Biomass Briquetting Technology for Northern Regions of Karnataka Using Tamarind Seed Powder as Binder. Journal of Advances in Science and Technology, 12(25),

15. Zhang, X., Xu, D., Xu, Z., \& Cheng, Q. (2001). The effect of different treatment conditions on biomass binder preparation for lignite briquette. Fuel Processing Technology, 73(3), 185196.

16. Mayoral, M.C., \& Izquiredo. (2001). DSC Study of Curing in Smokeless Briquetting.

17. Blesa, M. J., Miranda, J. L., Moliner, R., Izquierdo, M. T., \& Palacios, J. M. (2003). Low-temperature co-pyrolysis of a low-rank coal and biomass to prepare smokeless fuel briquettes. Journal of Analytical and Applied Pyrolysis, 70(2), 665-677.

18. Patomsok, W. (2008). Density Equation of BioCoal Briquette and Quality of Maize Cob in Thailand. American J. of Applied Science, 5(12), 1808-1811.

19. Chu, M., Zhu, S., Yi, Y., \& Deng, Y. (2012). Characteristics of pyrolysis products of bori lignite briquette. Energy Procedia, 16, 307-313.

20. Oyelaran, O. A., \& Tudunwada, Y. Y. (2015). Determination of the bioenergy potential of melon shell and corn cob briquette. Iranica Journal of Energy and Environment, 6(3), 167-172.

21. Kumar, G. S., Rao, D. C., Sreeramulu, D. D., \& Madhavi, S. K. (2016). Evaluation of Boiler Efficiency of Bio Briquettes by Indirect Method. International Journal of Mechanical Engineering and Technology, 7(6).

22. Ohimain, E. I. (2010). Emerging bio-ethanol projects in Nigeria: Their opportunities and challenges. Energy Policy, 38(11), 7161-7168. 
Ibrahim MS et al., Saudi J Eng Technol, June., 2020; 5(6): 285-290

23. FAO.(2015). FAOSTAT.

http://faostat3.fao.org/browse/area/159/E

[accessed 17.01.16].

24. FAO.(2016). Country fact sheet 2016. http://www.fao.org/nr/water/aquastat/data/cf/readP df.html?f=NGA-CF_eng.pdf $>$ [accessed 17.01.16].

25. Raju, A. I., Praveena, U., Satya, M., Ramya, J., \& Saveswara, R. (2014). Studies on development of fuel briquettes using biodegradable waste materials. Journal of bioprocessing and chemical engineering, (1), 6.

26. Onuegbu, T. U., Ekpunobi, U. E., Ogbu, I. M., Ekeoma, M. O., \& Obumselu, F. O. (2011). Comparative studies of ignition time and water boiling test of coal and biomass briquettes blend. IJRRAS, 7(2), 153-159.

27. Nuriana, W., \& Anisa, N. (2014). Synthesis preliminary studies durian peel bio bri

28. Tiwari, C., \& Beck, S. (2011). Producing fuel briquettes from sugarcane waste. $E W B-U K$ National Research \& Education Journal, 220-550.

29. Grover, P. D., \& Mishra, S. K. (1996). Biomass briquetting: technology and practices (No. 46). Bangkok, Thailand: Food and Agriculture Organization of the United Nations.

30. Karaosmanoglu, F. (2000). Biobriquetting of rapeseed cake. Energy Sources, 22(3), 257-267.

31. Grover, P. D., \& Mishra, S. K. (1995, April). Regional Wood Energy Development Programme in India. In Proceedings of International Workshop on Biomass Briquetting, New Delhi (India).

32. Shaaban, M., \& Petinrin, J. O. (2014). Renewable energy potentials in Nigeria: Meeting rural energy needs. Renewable and Sustainable Energy Reviews, 29, 72-84.

33. Schoene, D., Killmann, W., von Lüpke, H., \& Wilkie, M. L. (2007). Definitional issues related to reducing emissions from deforesation in developing countries (Vol. 5). Rome: Food and Agriculture Organization of the United Nations.

34. Ullah, K., Sharma, V. K., Dhingra, S., Braccio, G., Ahmad, M., \& Sofia, S. (2015). Assessing the lignocellulosic biomass resources potential in developing countries: A critical review. Renewable and Sustainable Energy Reviews, 51, 682-698.

35. Ben-Iwo, J., Manovic, V., \& Longhurst, P. (2016). Biomass resources and biofuels potential for the production of transportation fuels in Nigeria. Renewable and sustainable energy reviews, 63, 172-192.

36. Ben-Iwo, J., Manovic, V., \& Longhurst, P. (2016). Biomass resources and biofuels potential for the production of transportation fuels in Nigeria. Renewable and sustainable energy reviews, 63, 172-192.

37. IEA.(2006). World Energy Outlook, 2006. IEA/OECD, Paris, France, 596.

38. cfnielsen.com
39. Joel, C.(2010). "Combustion Characteristics of Biomass Briquette", Fuel processing technology, Progress in Energy and Combustion Science, 30(2): 219-230.

40. Hayami, H., Wake, Y., Kojima, T., \& Yoshioka, K. (2001, September). Biocoal briquette and planting trees as an experimental CDM in China. In Annual Meeting of the Society for Environmental Economicsts and Policy Studies (pp. 29-30).

41. Erickson, S., \& Prior, M. (1990). The Briquetting of Agricultural Wastes for Fuel. FAO, Environment and Energy paper 11. FAO, viadelle Terme di Caracalla, 000100 Rome Italy.

42. Forestry Residues".(1965). Proceedings of the sixth Canadian Bio-energy R \& D Seminar held out Richmond, British Columbia, 16-18.

43. Ichu, C., Nwogu, N., Agulanna, A., \& Nwakanma, H. (2019). Potentials of biomass briquetting and utilization: the Nigerian perspective. Pacific International Journal, 2(4), 46-54.

44. Abiodun, S. Momodu., \& Garba, B.M. (2018). Briquetting of agro-wates in northern Nigeria: meeting household energy needs and reducing environmental damage. https://www.inclusivebusiness.net/ibvoices/briquetting-agro-wates-northern-nigeriameeting-household-energy-needs-and-reducing

45. Simonyan, K. J., \& Fasina, O. (2013). Biomass resources and bioenergy potentials in Nigeria. African Journal of Agricultural Research, 8(40), 4975-4989.

46. Giwa, A., Alabi, A., Yusuf, A., \& Olukan, T. (2017). A comprehensive review on biomass and solar energy for sustainable energy generation in Nigeria. Renewable and Sustainable Energy Reviews, 69, 620-641.

47. Liu, S. Y. (2003). Development and test study on biomass (straw) briquettes combustion equipment. Zhengzhou. Henan Agricultural University.

48. SU, J. L., ZHAO, X. W., \& WANG, W. (2009). Research status and development of the biomass briquette fuel. Energy Conservation Technology, 2.

49. Felfli, F. F., Rocha, J. D., Filippetto, D., Luengo, C. A., \& Pippo, W. A. (2011). Biomass briquetting and its perspectives in Brazil. Biomass and bioenergy, 35(1), 236-242.

50. Nilsson, D., Bernesson, S., \& Hansson, P. A. (2011). Pellet production from agricultural raw materials-A systems study. Biomass and Bioenergy, 35(1), 679-689.

51. Hu, J., Lei, T., Wang, Z., Yan, X., Shi, X., Li, Z., ... \& Zhang, Q. (2014). Economic, environmental and social assessment of briquette fuel from agricultural residues in China-A study on flat die briquetting using corn stalk. Energy, 64, 557-566.

52. World Health Organization. (2016). Burning opportunity: clean household energy for health, sustainable development, and wellbeing of women and children. 
Ibrahim MS et al., Saudi J Eng Technol, June., 2020; 5(6): 285-290

53. Bailey, J., Barnum, H., Berger, M., BERGEVIN, Y., Collishaw, N., SILVA, V., ... \& Gupta, P. (1995). Bellagio statement on tobacco and sustainable development. Canadian Medical Association Journal, 153(8).

54. Quddus, M. A., \& Mia, M. M. U. (2010). Agricultural research priority: vision-2030 and beyond. Final report on food availability and consumption, postharvest losses, agro-processing technology, food safety and human nutrition, Bangladesh Agricultural Research Council, Dhaka, 1-48.

55. Yumak, H., Ucar, T., \& Seyidbekiroglu, N. (2010). Briquetting soda weed (Salsola tragus) to be used as a rural fuel source. Biomass and Bioenergy, 34(5), 630-636.

56. Elbehri, A., Segerstedt, A., \& Liu, P. (2013). Biofuels and the sustainability challenge: $a$ global assessment of sustainability issues, trends and policies for biofuels and related feedstocks. Food and Agriculture Organization of the United Nations (FAO).

57. ECN. (2013). National energy policy [Draft revised edition].

58. Kaygusuz, K. (2011). Energy, electricity and socioeconomic transformation of rural regions in developing countries. Energy Sources, Part B: Economics, Planning, and Policy, 6(4), 384-394.
59. Karekezi, S. (2002). Renewables in Africameeting the energy needs of the poor. Energy policy, 30(11-12), 1059-1069.

60. Ministry of Energy (MoE). (2002). Republic of KENYA Study on Kenya's Energy Demand, Supply and Policy Strategy for Households, Small Scale Industries and Service Establishments. Project Report

61. Kituyi, E. (2004). Towards sustainable production and use of charcoal in Kenya: exploring the potential in life cycle management approach. Journal of Cleaner Production, 12(810), 1047-1057.

62. Mutimba, S., \& Barasa, M. (2005). National charcoal survey: Summary report. Exploring the potential for a sustainable charcoal industry in Kenya. Energy for Sustainable Development Africa (ESDA), 4-22.

63. Pennise, D. M., Smith, K. R., Kithinji, J. P., Rezende, M. E., Raad, T. J., Zhang, J., \& Fan, C. (2001). Emissions of greenhouse gases and other airborne pollutants from charcoal making in Kenya and Brazil. Journal of Geophysical Research: Atmospheres, 106(D20), 24143-24155.

64. Bonjour, S., Adair-Rohani, H., Wolf, J., Bruce, N. G., Mehta, S., Prüss-Ustün, A., ... \& Smith, K. R. (2013). Solid fuel use for household cooking: country and regional estimates for 1980 2010. Environmental health perspectives, 121(7), 784-790. 